\title{
Wybrane aspekty pomiarów i monitorowania podczas spawania tukowego
}

\author{
Some aspects of monitoring and measurements \\ during arc welding
}

\section{Streszczenie}

Znajomość rzeczywistych parametrów spawania łukowego jest niezbędna z punktu widzenia bieżącej kontroli procesu, sprawdzania zgodności z instrukcjami WPS, wdrażania i uznawania nowej technologii itp. Jako rozwinięcie standardowych przyrządów pomiarowych mogą tu znaleźć zastosowanie systemy monitorujące. Oprócz pomiaru i biernej rejestracji, niektóre z nich mogą sprawować funkcje automatycznego nadzoru połączonego $\mathrm{np}$. z sygnalizacją przekroczeń, przewidywaniem niezgodności spawalniczych, a nawet ingerencją w pracę maszyny i proces spawalniczy. W artykule przedstawiono wybrane aspekty pomiarów i monitorowania podstawowych parametrów spawania łukowego MIG/MAG oparte na badaniach testowych.

Słowa kluczowe: pomiary; monitorowanie; spawanie łukowe

\begin{abstract}
The knowledge of real parameters values of an arc welding is to be necessary for on-line process control, observing WPS data as well as implementation of new welding procedures. Beside conventional measuring devices some monitoring systems can be applied. Such systems either can be used for simple measurement recording of work parameters but some of them can be used for automatic control with simultaneous signaling of process parameters deviations or prediction of possible welding imperfections as well as adjustment of welding machines controllers or even on-going process. Some aspects of basic MIG/MAG welding parameters measurement and monitoring are presented in this paper.
\end{abstract}

Keywords: adhesive bonding; application of adhesive bonding; adhesives

\section{Wprowadzenie}

W odniesieniu do przemysłowych procesów produkcyjnych, także spawalniczych, monitorowanie to całokształt działań oraz środków niezbędnych do bieżącej obserwacji (poprzez pomiar w czasie rzeczywistym), rejestracji (zapamiętywania), filtrowania, a niekiedy także interpretacji (np. odniesienia do nałożonych progów) określonych parametrów (rys. 1) [1,2,12]. Konieczność i przydatność monitorowania wynika nie tylko z wymogów norm jakościowych, ale może ułatwiać późniejsze naprawy i konserwację, upraszczać spory gwarancyjne itp.

Powszechna komputeryzacja i informatyzacja urządzeń spawalniczych sprzyja rozwojowi systemów monitorowania, pozwalając na rejestrację coraz większej liczby parametrów z wysoką rozdzielczością i dokładnością, a także zaawansowane filtrowanie i przetwarzanie zmierzonych wielkości. Odrębnym, zwykle wykraczającym poza ramy monitorowania zagadnieniem, jest automatyczny nadzór i diagnostyka obserwowanego procesu. W wyniku interpretacji mierzonych sygnałów mogą być podejmowane działania korekcyjne, w tym awaryjne zatrzymanie procesu (rys. 2).

W normach serii PN-ISO 9000 zwrócono uwagę na procesy produkcyjne specjalne, do których zaliczono spawalnictwo, których efekt nie może być w pełni sprawdzony podczas kontroli i badania, a powstałe wady mogą ujawnić się dopiero w trakcie użytkowania wyrobu. Proces taki musi być realizowany przez wysoko wykwalifikowanych i uprawnionych pracowników, a jego parametry muszą być w sposób ciągły monitorowane i nadzorowane, aby zapewnić spełnienie

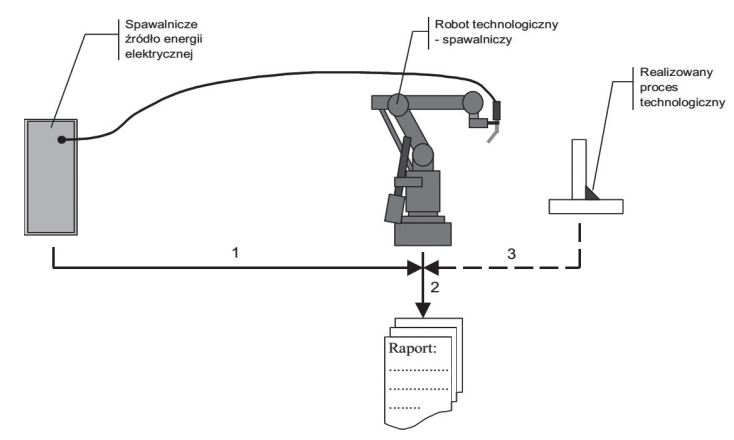

Rys. 1. Idea monitorowania podczas zrobotyzowanego spawania łukowego: 1 - czujniki stanu spawalniczego źródła energii elektrycznej, 2 - parametry pracy robota (np. w funkcji kroków progra$\mathrm{mu}), 3$ - parametry realizowanego procesu [2]

Fig. 1. The principle of on-line monitoring of robotized arc welding: 1 - welding power source parameter sensors, 2 - welding robot parameters (e.g. as a function of program steps), 3 - welding process parameters [2]

dr inż. Paweł Cegielski, Prof. dr hab. inż. Andrzej Kolasa, mgr inż. Marcin Kuczyński, inż. Renata Rostowska - Politechnika Warszawska.

Autor korespondencyjny/Corresponding author: pcegiels@wip.pw.edu.pl 


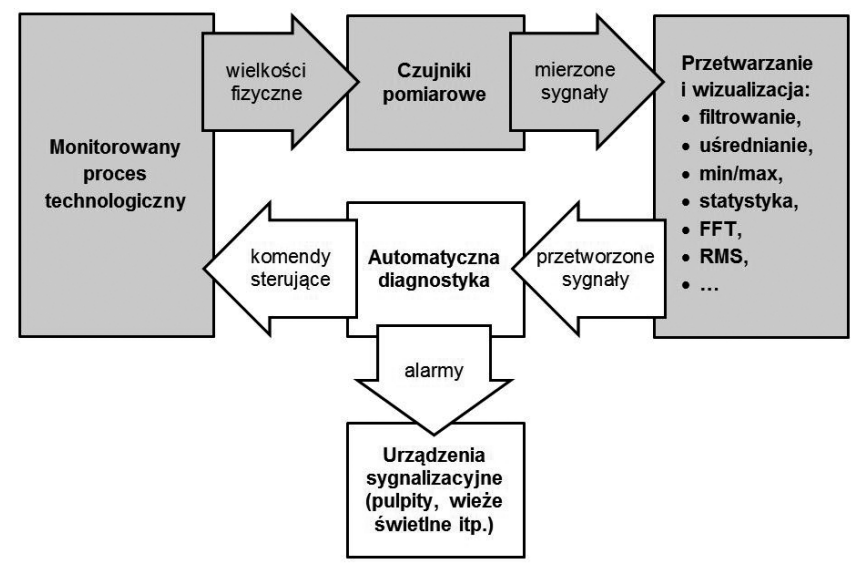

Rys. 2. Struktura systemu monitorowania i diagnostyki procesu technologicznego

Fig. 2. The scheme of monitoring and diagnostic of manufacturing process system

określonych wymagań [11]. Z omawianym zagadnieniem związane są wspomniane już normy serii ISO 9000, a także serii ISO 3834 czy PN-EN ISO 3834-3:2007. Od 1 lipca 2014 wszystkich producentów konstrukcji stalowych i aluminiowych przeznaczonych na rynek Unii Europejskiej obowiązuje norma EN1090, nakładająca obowiązek wydawania znaku CE na wszystkie wyroby, a w zakładzie produkcyjnym powinien zostać wdrożony certyfikowany system ZKP (Zakładowej Kontroli Produkcji) [13]. Logiczną konsekwencją nowych wymagań może być wdrożenie systemu monitorującego parametry i przebieg wykonania wszystkich spoin.

Spośród szeregu parametrów i ustawień towarzyszących spawaniu łukowemu MIG/MAG monitorowanie dotyczy najczęściej prądu spawania, napięcia łuku, prędkości podawania drutu elektrodowego oraz wydatku (przepływu) gazu osłonowego. Pozostałe, takie jak średnica i gatunek drutu elektrodowego, rodzaj lub skład gazu osłonowego oraz korekty specyficzne dla odmiany procesu i typu źródła spawalniczego mogą zostać wprowadzone dodatkowo, jako parametry stałe. Prędkość spawania, a dodatkowo orientacja elektrody, mogą być monitorowane przede wszystkim podczas spawania zmechanizowanego i zautomatyzowanego, z wykorzystaniem dodatkowego osprzętu pomiarowego lub w oparciu o sygnały przekazywane z układu sterującego maszyny manipulacyjnej. W przypadku spawania ręcznego, prędkość spawania może zostać określona pośrednio, poprzez wprowadzenie długości spoiny i skonfrontowanie jej $z$ automatycznie zmierzonym czasem jej wykonania. Znajomość prędkości spawania jest konieczna w systemach deklarujących kontrolę energii liniowej spawania.

W praktyce, stosowane są różne strategie monitorowania parametrów spawania. W najprostszych systemach, w tym starszych, pojedyncza spoina opatrywana jest datą i godziną wykonania oraz liczbowym przedstawieniem jedynie średnich wartości podstawowych parametrów, osiągniętych w całym cyklu. Nowoczesne, zaawansowane przemysłowe systemy monitorujące, a także stacje laboratoryjne i badawcze, pozwalają na przedstawienie $w$ formie graficznej przebiegów obrazujących chwilowe zmiany poszczególnych parametrów w dziedzinie czasu.

Dostępne na rynku spawalnicze systemy monitorujące można podzielić na dwie główne grupy:

1) uniwersalne, zewnętrzne w stosunku do monitorowanych urządzeń, zarówno o charakterze przemysłowym, jak i badawczym; najczęściej przyjmują postać zewnętrznych przystawek pomiarowych zaopatrzonych w szereg opcjonalnych czujników pomiarowych, okablowania itp.,

2) dedykowane, dostosowane do urządzeń konkretnego producenta, zarówno zewnętrzne (przystawki komuniku- jące się z wewnętrzną aparaturą pomiarową urządzenia) jak i wbudowane, przede wszystkim w spawalnicze źródła energii.

Monitorowanie spawania łukowego może przy tym obejmować m.in.:

- rejestrację wybranych parametrów technologicznych w funkcji czasu,

- szacowanie wprowadzanego ciepła (energii liniowej), kosztów, zużycia materiałów itp.,

- monitorowanie pracy spawacza lub operatora (w tym statystyka czasu pracy),

- monitorowanie stanu maszyn (w tym błędów i awarii),

- opcjonalnie, kontrolę jakości procesu, poprzez analizę zarejestrowanych parametrów:

- odchyłek parametrów od założonych progów (tzw. progowanie),

- innych anomalii parametrów spawania,

- alarmowanie o przekroczeniach,

- korygowanie parametrów, reakcje awaryjne (np. funkcje wbudowane w niektóre spawalnicze urządzenia zasilające)

- monitorowanie i rejestracja do celów badawczych...

\section{Wybrane problemy pomiarowe}

Niezależnie od stopnia zaawansowania systemu, istotna jest jakość (dokładność, rozdzielczość) mierzonych parametrów. Przy przetwarzaniu ciągłego sygnału analogowego na dyskretny sygnał cyfrowy należy określić ilość pomiarów (próbek) w jednostce czasu (zwykle sekundzie) - częstotliwość próbkowania. Zgodnie z twierdzeniem Whittakera-Nyquista-Kotielnikowa-Shannona, częstotliwość próbkowania powinna być co najmniej dwa razy większa niż maksymalna częstotliwość przetwarzanego sygnału. Zastosowanie zbyt niskiej częstotliwości może skutkować nadmiernym uproszczeniem, a nawet zniekształceniem mierzonego sygnału i w konsekwencji prowadzić do jego błędnej interpretacji (rys. 3) [9]. Jest to szczególnie istotne w przypadku analizy przebiegów spawania łukowego MIG/MAG, zwykle silnie odkształconych (niesinusoidalnie), często połączonych z zakłóceniami, w tym także tętnieniami pochodzących od układów przełączających wewnętrznego inwertora (dotyczy coraz powszechniej stosowanych źródeł inwertorowych). Oprócz częstotliwości próbkowania, wysoka jakość pomiaru wymaga odpowiednio szerokiego pasma pomiarowego (miernika, sondy pomiarowej), szybkiego reagowania na zbocza mierzonych przebiegów i wysokiej rozdzielczości pomiaru.

Prawidłowe warunki pomiaru (wysoka częstotliwość próbkowania, rozdzielczość itp.) w połączeniu z wysoką powtarzalnością i dokładnością pomiaru są domeną aparatury laboratoryjnej i badawczej, takiej jak oscyloskopy, analizatory sygnałowe, przyrządy wirtualne, a także specjalne, ręczne mierniki i multimetry [3,4]. Konieczność zapewnienie odpowiednich warunków pomiaru nie zawsze oznacza szczegółową rejestrację i wizualizację wyników. Na potrzeby spawalniczych pomiarów i monitorowania najczęściej wystarczające okazuje się przetworzenie wyników serii dokładnie zmierzonych parametrów do wartości średnich, a następnie przedstawienie:

- zwykle cyfrowe, na wyświetlaczu ręcznego miernika, prądu spawania i napięcia łuku,

- cyfrowe, na płycie czołowej urządzenia spawalniczego, prądu spawania i napięcia łuku,

- graficzne, obrazujące zmiany parametrów w dziedzinie czasu, jednak z ograniczoną częstotliwością nanoszenia na wykres (ok. 1-10Hz); ułatwia to obserwację i ocenę przebiegu procesu przy jednoczesnym zminimalizowaniu ilości rejestrowanych danych. 
a)

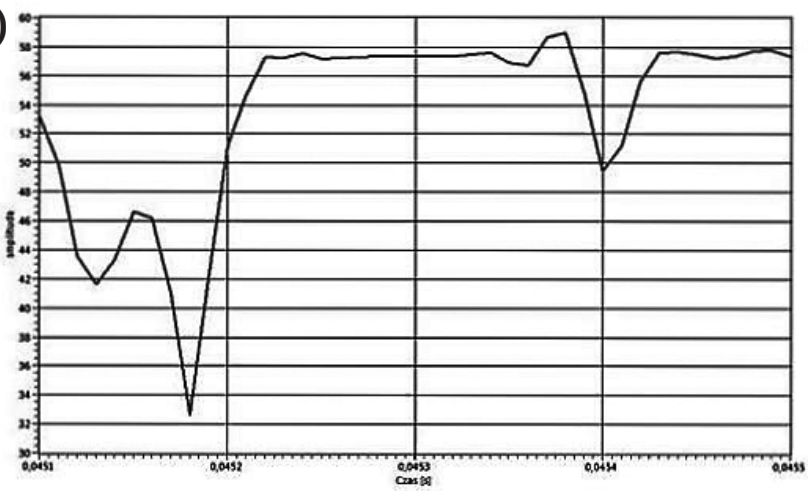

b)

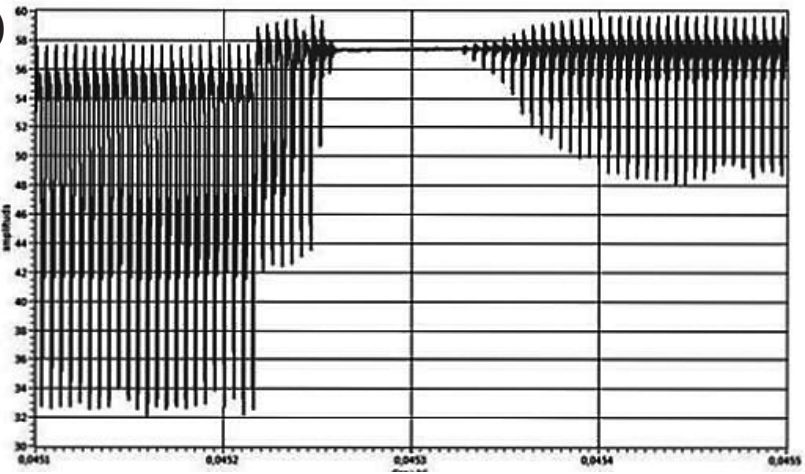

Rys. 3. Porównanie fragmentu tego samego przebiegu prądu spawania metodą MAG zarejestrowanego przy: a) niedostatecznej $(100 \mathrm{kHz})$, b) wystarczającej $(10 \mathrm{MHz})$ częstotliwości próbkowania [5] Fig. 3. The comparison of a piece of MAG welding current waveforms recorded with: a) insufficient $(100 \mathrm{kHz})$ and b) sufficient $(10 \mathrm{MHz})$ sampling frequency [5]

Taka postać i ilość informacji nie pozwoli na szczegółową analizę procesu, w tym wychwycenie krótkotrwałych zaburzeń, to możliwa będzie łatwa, bieżąca ocena zgodności parametrów z założeniami technologicznymi i zapisami instrukcji WPS, kontrola pracy urządzenia, a także wychwycenie istotnych przekroczeń dopuszczalnych poziomów kontrolowanych parametrów.

W spawalniczych obwodach pomiarowych ważne jest filtrowanie (usuwanie zakłóceń) i uśrednienie dużej liczby danych. Z pomocą przychodzą same przyrządy pomiarowe, np. w miejsce dawniej stosowanych boczników do pomiaru prądu spawania obecnie mogą być zastosowane amperomierze cęgowe z półprzewodnikowymi detektorami hallotronowymi (wykorzystującymi efekt Halla). W oscyloskopach dostępne są różne tryby uśredniania i przekształcania wyników pomiaru, w tym do postaci wartości skutecznej. Obecnie także $\mathrm{w}$ wielu miernikach cęgowych $\mathrm{i}$ uniwersalnych multimetrach można znaleźć tryb przekształcania wyniku do postaci wartości skutecznej, w tym uwzględniającej składową stałą i zmienną mierzonego sygnału (oznaczane przeważnie jako TRUE RMS AC+DC).

Wartość skuteczna - oznacza taką miarę sygnału przemiennego, która w ciągu pojedynczego okresu wywoła na obciążeniu ten sam efekt cieplny, co przepływ prądu stałego o tej samej wartości. Wartość skuteczna prądu przemiennego jest to taka wartości prądu stałego, który w czasie trwania pojedynczego okresu przebiegu zmiennego spowoduje identyczny efekt cieplny (ciepło Joule'a) co prąd zmienny:

$$
I=\sqrt{\frac{1}{T} \int_{t_{0}}^{t_{0}+T} i^{2}(t) d t}
$$

Analogicznie, wyznaczana jest wartość skuteczna napięcia. Jak widać, wartość skuteczna określa parametry energetyczne mierzonego sygnału.
Na rysunku 4 przedstawiono przykładowy przebieg prądu spawania zarejestrowany podczas spawania metodą MAG (źródło inwertorowe, tryb MAG Puls). Dopiero jego przekształcenie do postaci wartości skutecznej w połączeniu z filtrowaniem (dolnoprzepustowym, m.in. w celu usunięcia z przebiegu efektów przełączeń tranzystorów źródeł inwertorowych), pozwala na łatwą i szybką analizę przebiegu procesu - identyfikację znaczących przekroczeń parametrów, zaników łuku i zakłóceń, a po dalszych przekształceniach, nawet rozpoznanie niektórych niezgodności spawalniczych [10]. W przedstawionym przypadku, przy wyznaczaniu okresowej wartości skutecznej przebiegów prądu i napięcia przyjęto za podstawę czasu wartość $5 \mathrm{~ms}$.
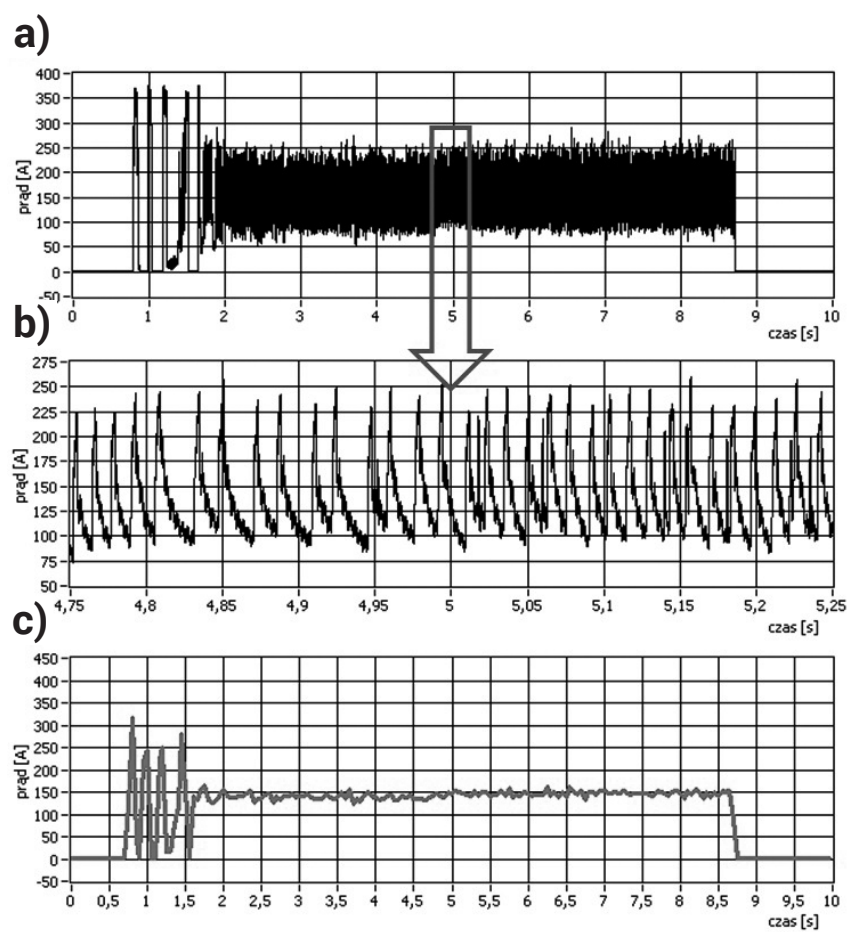

Rys. 4. Porównanie przebiegów prądu zarejestrowanych podczas spawania MAG źródłem inwertorowym: a) wartości chwilowe niefiltrowane: b) wartości chwilowe niefiltrowane dla fragmentu przebiegu, c) wartości skuteczne filtrowane [10]

Fig. 4. The comparison of MAG welding current waveforms with the use of inverter power source: a) non-filtered instantaneous values, b) marked piece of current waveform of a), c) filtered current RMS values waveform [10]

Oznaczenie RMS (ang. Root Mean Square), stosowane na szeregu zaawansowanych miernikach pomiarowych, oznacza pomiar rzeczywistej wartości skutecznej sygnatu przemiennego. Typowo, woltomierze i amperomierze (multimetry) na zakresach DC (stałych - jednokierunkowych) mierzą napięcie średnie, a większość mierników przebiegów zmiennych AC w ogóle nie uwzględnia składowej stałej (odcina kondensatorem, w tym tanie mierniki opisane jako TRUE RMS). Poprawne wskazania dają tylko dla sinusoidalnych przebiegów przemiennych AC (obciążeń liniowych). Dopiero dobrej klasy (i zwykle znacznie droższy) mierniki oznaczone symbolem TRUE RMS AC+DC pozwalają na pomiar przebiegów odkształconych (niesinusoidalnych) zawierających składową stałą i zmienną. Na rysunku 5 zestawiono dwa odczyty napięcia dla fragmentu przebiegu pulsującego DC zarejestrowanego przez oscyloskop, przy dwóch nastawach pomiarowej

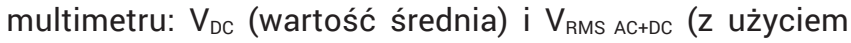
funkcji TRUE RMS AC+DC). Jak widać, odczytane wartość są zgodne z przeliczeniami oscyloskopu, jednak wartość skuteczna TRUE RMS AC+DC dała wynik ...niemal dwukrotnie większy! $[7,8]$ 


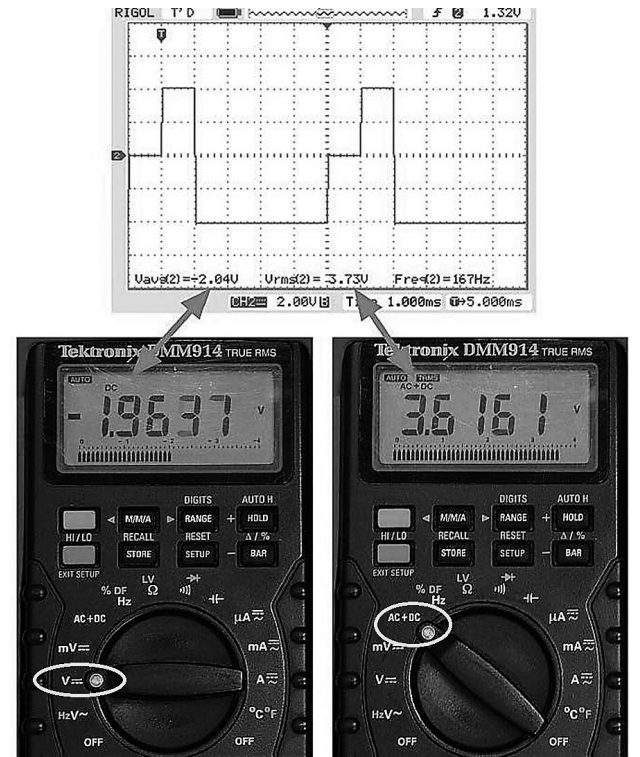

Rys. 5. Porównanie odczytów napięcia dla fragmentu przebiegu zarejestrowanego przez oscyloskop przy nastawie pomiarowej multimetru: a) $V_{D C}$, b) $V_{R M S A C+D C}$ [8]

Fig. 5. The comparison of welding voltage waveform values recorded by oscilloscope with the readouts on multimeter under settings: a) $V_{D C}$, b) $V_{R M S A C+D C}[8]$

W przypadku mierników z funkcją TRUE RMS AC+DC należy sprawdzić w jak szerokim zakresie częstotliwości uzyskiwany będzie dobrej jakości (dokładności) wynik pomiarów. W tablicy I przedstawiono przykładową charakterystykę użytkową wysokiej klasy multimetru laboratoryjnego na zakresie $\mathrm{V}_{\mathrm{RMS} \text { AC+DC }}$ (Yokogawa TY720).

Dokładność i rozdzielczość pomiaru, w rozbiciu na kolejne zakresy częstotliwości mierzonego sygnału opisana została ogólnym wzorem na błąd bezwzględny (uchyb):

$$
\begin{aligned}
\Delta \mathrm{X}= & \pm[(\text { klasa dokładności } \cdot \text { wskazanie }) / 100+ \\
& + \text { waga ostatniej cyfry })]
\end{aligned}
$$

Pierwszy człon wzoru odzwierciedla klasę przyrządu na danym zakresie i odnosi się do zmierzonego wskazania, drugi zaś uwzględnia wagę ostatniej cyfry (najmniejszej dającej się odczytać, zwykle jej wielokrotność). Multimetry można przy tym zakwalifikować do klasy laboratoryjnej $(0.05 \div 0,5)$, technicznej $(1,0 \div 1,5)$ i wskaźnikowej (pozostałe) [4].

\section{Prace eksperymentalne}

Celem eksperymentów była analiza i badania wybranych spawalniczych systemów nadzoru i monitorowania, zarówno zewnętrznych jak i wbudowanych w wytypowane urządzenia oraz konfrontacja wyników pomiarów prądu i napięcia podczas stosowania różnych przyrządów pomiarowych podczas napawania metodą MAG. Program badań zakładał wykonanie dwóch grup napoin:

- niemodyfikowanych, prostoliniowych, podczas pomiarów i rejestracji,

- z kontrolowanymi, sztucznie wywoływanymi zakłóceniami przebiegu procesu.

Napawano na powierzchni płytek ze stali konstrukcyjnej St3S (S235) o wymiarach 50 $\div 100 \times 100 \mathrm{~mm}$ i grubości $3 \div 4 \mathrm{~mm}$, metalicznie czystych i odtłuszczonych. Wykorzystano drut elektrodowy G3SI1 firmy ESAB o średnicy 0,8 i 1,0 mm oraz gaz osłonowy M21 (80\% $\mathrm{Ar}$ i $\left.20 \% \mathrm{CO}_{2}\right)$.

Badania prowadzono podczas zrobotyzowanego napawania różnymi odmianami metody MAG, dostępnymi w sterowanym cyfrowo źródle inwertorowym TPS 2700CMT firmy Fronius (zachowano oryginalne oznaczenia przyjęte dla badanych źródeł): MAG Puls (spawanie prądem pulsującym), MAG CMT (ang. Cold Metal Transfer, odmiana niskoenergetyczna MAG z pulsacją posuwu drutu elektrodowego) oraz MAG Synergic (spawanie łukiem niesterowanym, jednak z synergicznym sterowaniem parametrów wyjściowych źródła zasilania).

W pierwszej kolejności wykorzystano następujący sprzęt monitorujący:

- sterownik/rejestrator RCU 5000i (Fronius) - rejestracja prądu i napięcia,

- system wbudowany w układ sterowania robota IRp-6 (ZAP Robotyka - Zakład Inżynierii Spajania PW) - rejestracja pracy robota oraz jednego, zewnętrznego kanału pomiarowego poprzez RS-232C; w badaniach wykorzystano multimetr Metex M-4660A oraz hallotronową sondę prądową APPA 32,

- funkcje monitorująco - kontrolne wbudowane w źródło TPS 2700CMT (Fronius),

- wirtualny przyrząd pomiarowy KWR1 oparty na zewnętrznej karcie DAQ firmy National Instruments, przetwornikach pomiarowych prądu i napięcia (hallotronowych) oraz oprogramowaniu LabView (kaseta pomiarowa, opracowanie własne Zakładu Inżynierii Spajania PW); w badaniach wykorzystano do pomiarów i rejestracji prądu i napięcia (wartości średnich i skutecznych).

Do badań wytypowano ponadto następujące przyrządy pomiarowe ( $w$ nawiasie podano mierzone parametry oraz klasę w odniesieniu do wykonywanych pomiarów):

- multimetr Metex M-4660A (pomiar napięcia, klasa laboratoryjna),

- multimetr Metex M-3270D (pomiar napięcia, klasa laboratryjna/techniczna),

- multimetr APPA 305 (pomiar napięcia, pomiar wartości średniej i skutecznej AC+DC, VDC klasa laboratoryjna, VRMS AC+DC klasa techniczna),

- multimetr Yokogawa TY720 (pomiar napięcia, pomiar wartości średniej i skutecznej AC+DC, VDC klasa laboratoryjna, VRMS AC+DC klasa laboratoryjna/techniczna),

- miernik cęgowy TES 3060 (pomiar prądu, klasa techniczna),

Tablica I. Dokładność multimetru laboratoryjnego na zakresie $\mathrm{V}_{\mathrm{RMS} A C+D C}$ (Yokogawa TY720)

\begin{tabular}{|c|c|c|c|c|c|c|}
\hline \multirow[b]{2}{*}{ Zakres } & \multirow[b]{2}{*}{ Rozdzielczość } & \multicolumn{5}{|c|}{ Dokładność dla danych częstotliwości } \\
\hline & & $10 \mathrm{~Hz}-20 \mathrm{~Hz}$ & $\begin{array}{r}20 \mathrm{~Hz}-1 \mathrm{KHz} \\
1 \mathrm{kHz}-10 \mathrm{kHz}\end{array}$ & $10 \mathrm{kHz}-20 \mathrm{kHz}$ & $20 \mathrm{kHz}-50 \mathrm{kHz}$ & $50 \mathrm{kHz}-100 \mathrm{KHz}$ \\
\hline $5 \mathrm{~V}$ & $0.0001 \mathrm{~V}$ & \multirow{4}{*}{$\pm(1.5 \%+10)$} & \multirow{4}{*}{$\pm(0.5 \%+10)$} & \multirow{4}{*}{$\pm(1 \%+10)$} & \multirow{4}{*}{$\pm(2 \%+10)$} & \multirow{4}{*}{$\pm(5 \%+20)$} \\
\hline $50 \mathrm{~V}$ & $0.001 \mathrm{~V}$ & & & & & \\
\hline $500 \mathrm{~V}$ & $0.01 \mathrm{~V}$ & & & & & \\
\hline $1000 \mathrm{~V}$ & $0.1 \mathrm{~V}$ & & & & & \\
\hline
\end{tabular}

Table I. The accuracy of laboratory multimeter on the range $V_{\text {RMS AC+DC (Yokogawa TY720) }}$ 
- miernik cęgowy APPA 138 (pomiar prądu, pomiar wartości średniej i skutecznej AC+DC, klasa techniczna),

- sonda prądowa APPA 32 (klasa techniczna),

- przetworniki hallotronowe wbudowane w kasetę przyrządu wirtualnego KWR1,

- oscyloskop Siglent SDS1072CML 70MHz (rejestracja i pomiar prądu i napięcia, pomiar wartości średniej i skutecznej AC+DC),

- mierniki wbudowane do źródła spawalniczego TPS 2700CMT (klasa wskaźnikowa).

Prąd spawania mierzono na przewodzie masowym. Napięcie łuku kontrolowano pomiędzy podajnikiem drutu elektrodowego a miejscem podłączenia masy do obrotowego stołu spawalniczego.

Po wstępnej serii prostoliniowych, niezakłóconych napoin wykonywanych różnymi odmianami metody MAG przystąpiono do celowego wywoływania zakłóceń. W pierwszej kolejności napoina testowa układana była poprzecznie na napoinach leżących w 15-o milimetrowych odstępach. Rezultaty, na przykładzie próby nr 11 (MAG CMT, nastawa prądu 120A, nastawa napięcia 11,5V, prędkość napawania $0,3 \mathrm{~m} / \mathrm{min}$, średnica drutu $1,0 \mathrm{~mm}$ ), pozwoliły na sformułowanie szeregu ogólnych spostrzeżeń dotyczących badanych systemów monitorujących (rys. 6):

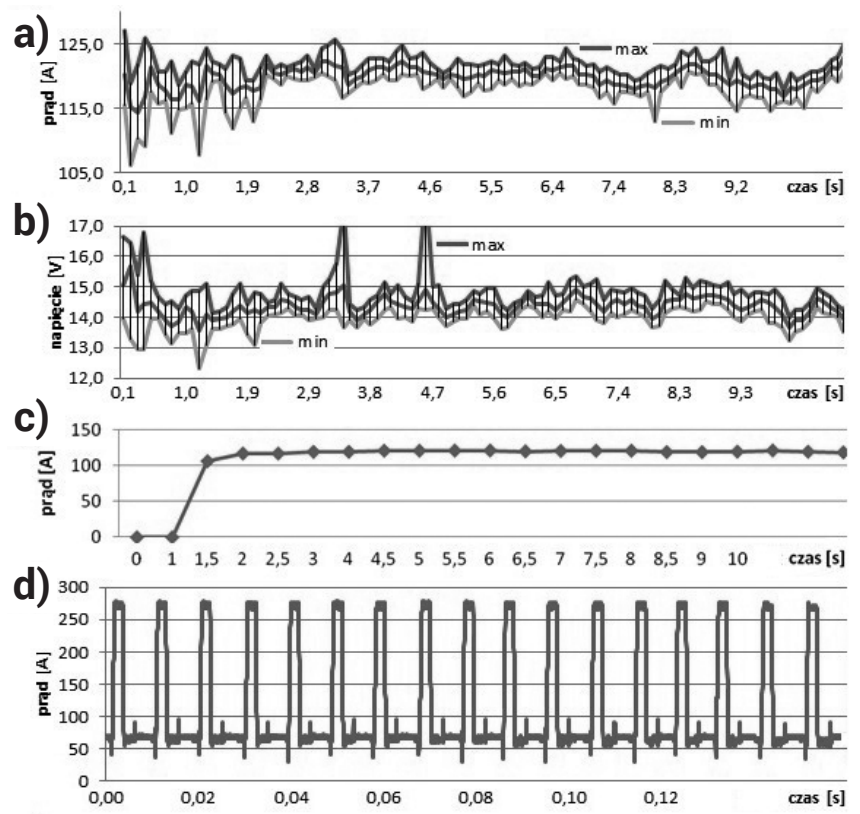

e)

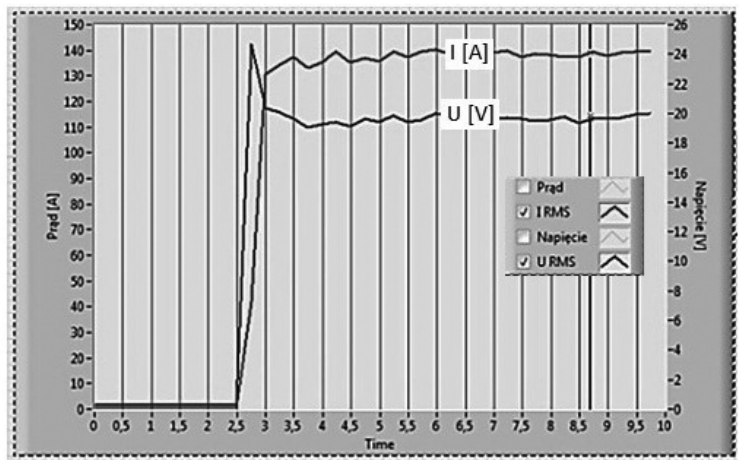

Rys. 6. Przebiegi zarejestrowane podczas napawania zakłóconego napoinami poprzecznymi: a) prąd spawania, RCU 5000i, b) napięcie tuku RCU5000i, c) prąd spawania, robot IRp-6, d) prąd spawania, oscyloskop Siglent SDS1072CML, przetworzone przez MS Excel, e) prąd spawania i napięcie łuku w fazie początkowej, wirtualny przyrząd pomiarowy KWR1, aplikacja LabView

Fig. 6. Welding current and voltage waveforms recorded while surfacing disturbed by transverse surface weld: a) welding current, RCU 5000i, b) arc voltage RCU 5000i, c) welding current, robot IRp-6, d) welding current, oscilloscope Siglent SDS 1072CML, transformed by MS Excel, e) welding current and arc voltage during starting phase, virtual measuring unit KWRI in LabView application
1. Komercyjny system RCU 5000i rejestrował parametry przekazywane wprost ze źródła spawalniczego. Zapisane na karcie SD odczytywano w dedykowanym oprogramowaniu Fronius Xplorer, gdzie mogły być wyświetlane w postaci wykresów z uwzględnieniem wartości minimalnych, maksymalnych i średnich (rys. 6/a,b) lub eksportowane do formatu Excel. Widać, że przyjęta metoda uśredniania i prezentacji pozwala na szybką i skuteczną ocenę stabilności procesu (widać zakłócenia spowodowane napawaniem na nierównym podłożu) oraz ewentualnych przekroczeń wartość dopuszczalnych.

2. System wbudowany robota IRp-6 bazuje na zewnętrznym multimetrze Metex M-4660A i sondzie prądowej APPA 32. Wskazania miernika zapisywane są w pliku tekstowym razem ze szczegółowymi informacjami o pracy robota. Przytoczony fragment raportu wskazuje na ok. $1 \mathrm{~Hz}$ częstotliwość przesyłania danych pomiarowych z multimetru, opatrzonych datą i czasem wystąpienia:

2015-11-09 19:14:32 Start systemu

2015-11-09 19:14:44 WY[7]=0 - kasowanie błędu 2015-11-09 19:14:45 0:170 SKOK

2015-11-09 19:14:45 0:10 POZ

(...)

2015-11-09 19:16:32 pomiar DC-0.0001 V

2015-11-09 19:16:33 pomiar DC 0.0013 V

2015-11-09 19:16:33 pomiar DC 0.1753 V

2015-11-09 19:16:34 pomiar DC 0.1917 V

2015-11-09 19:16:45 pomiar DC 0.1931 V

Dane $z$ raportu eksportowano do programu Excel, gdzie były przeliczane zgodnie z przełożeniem sondy prądowej i nanoszone na wykres (rys. 6/c). Widać, ze przyjęta rozdzielczość rejestracji nie była wystarczająca do ujawnienia niestabilności napawania, maskując je. Z drugiej strony, otrzymano łatwy do szybkiej oceny i obliczeń energii liniowej obraz, zbliżony do doraźnych odczytów z ręcznych mierników prądu i napięcia.

3. Zamrożony widok ekranu oscyloskopu można było zapisać do pliku JPG lub eksportować wartości chwilowe do formatu CVS, np. w celu dalszej obróbki w środowisku MS Excel (rys. 6/d). Tego typu narzędzie pomiarowe nie sprawdza się podczas długotrwałych rejestracji (ograniczenia układów pamięci), a służą przede wszystkim do ujawniania szczegółów wewnątrz przebiegów. Z drugiej strony, zaopatrzone w wszechstronne możliwości przekształcania i filtrowania oraz obliczeń pozwalają na zaawansowana analizę urządzenia i procesu.

4. Wirtualny przyrząd pomiarowy KWR1, dzięki sterującej aplikacji napisanej w środowisku LabView, może symulować pracę dowolnego z omówionych narzędzi (rys. 6/e). Największy potencjał ujawnia się jednak podczas zaawansowanych przekształceń, jak FFT, histogramy czy wyodrębnienia wartości skutecznych, na potrzeby zautomatyzowanej analizy procesu, w tym identyfikacji zaburzeń i niezgodności [6,10].

Jednym z ciekawszych eksperymentów były próby symulowanego przepalenia, wywoływanego nieprzelotowymi nawiertami na spodniej (graniowej) stronie próbek, pokrywającymi się trajektorią napawania (rys. 7/a). Rezultaty, na przykładzie próby nr 15 (MAG PULS, nastawa prądu $115 \mathrm{~A}$, nastawa napięcia $20,5 \mathrm{~V}$, prędkość napawania $0,36 \mathrm{~m} / \mathrm{min}$, średnica drutu $1,0 \mathrm{~mm}$, dwa nawierty) pozwoliły na sformułowanie szeregu kolejnych spostrzeżeń dotyczących porównywanych systemów monitorujących:

1. Komercyjny system RCU 5000 i wskazał, w chwili pojawienia się przepaleń, spadki wartości prądu oraz nagłe, szpilkowe wzrosty napięcia, wskazujące na obecność istot- 
nych zakłóceń. Niezwykle pomocne okazały się w tym przypadku dodatkowe linie pokazujące wartości minimalne i maksymalne (rys. $7 / b, c)$. Z drugiej strony, podobne obrazy zmian prądu i napięcia mogą być spowodowane innymi zakłóceniami i w konsekwencji powodować różne niezgodności spawalnicze.

2. Pomimo uproszczonego toru pomiarowego, również system wbudowany robota IRp-6 ujawnił wystąpienie zaburzeń procesu poprzez nieznaczne obniżenie przebiegu prądu spawania w chwilach wystąpienia przepaleń (rys. 7/d).

3. Zarówno oscyloskop, jak i wirtualny przyrząd pomiarowy także ujawniły wystąpienie poważnych zaburzeń (rys. 7/e), dając materiał do dalszej obróbki i badań, w tym tak oczekiwanego automatycznego rozpoznawania i identyfikacji niezgodności spawalniczych [6,10].

a)
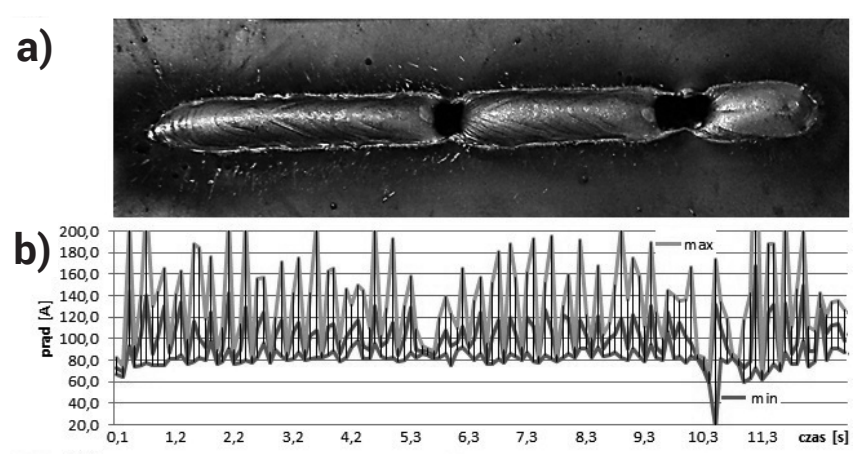

c)

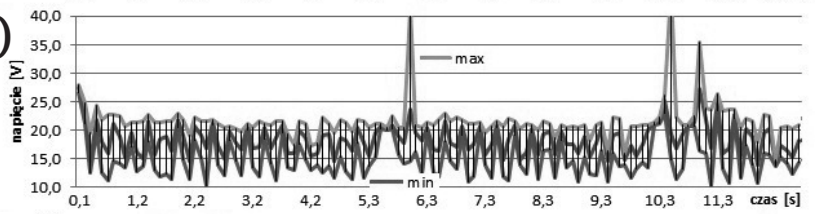

\section{d)}

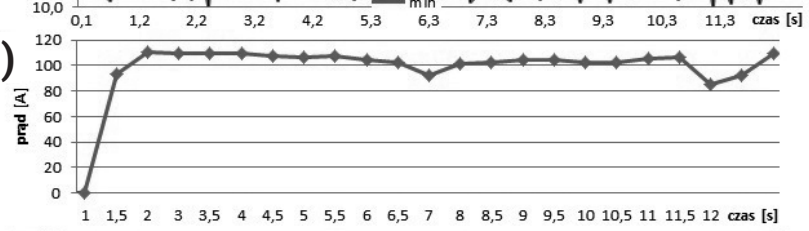

e)

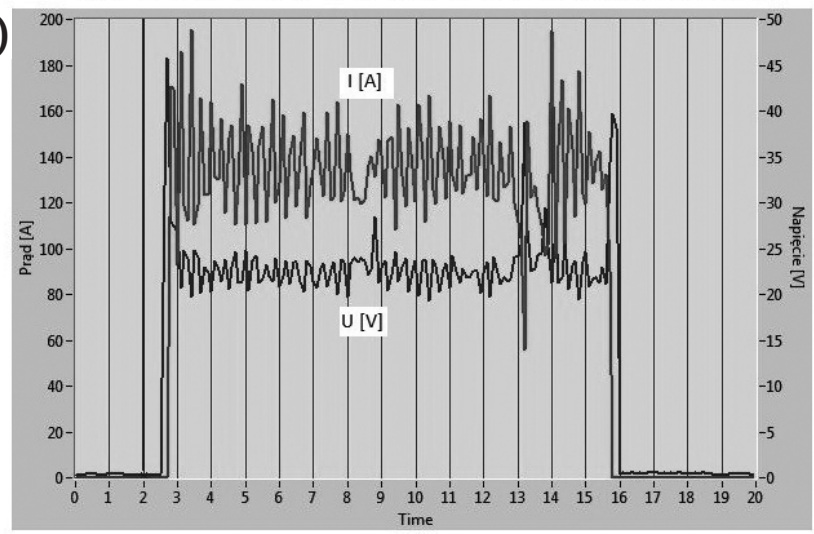

Rys. 7. Przebiegi zarejestrowane podczas napawania zakłóconego nawiertami powodującymi dwa przepalenia: a) widok napoiny, b) prąd spawania, RCU 5000i, c) napięcie łuku RCU5000i, d) prąd spawania, robot IRp-6, e) prąd spawania i napięcie łuku, wirtualny przyrząd pomiarowy KWR1, aplikacja LabView

Fig. 7. Welding current and voltage waveforms recorded while surfacing disturbed by two weld burn through: a) surface weld view, b) welding current, RCU $5000 \mathrm{i}, \mathrm{c}$ ) arc voltage RCU 5000i, d) welding current, robot IRp-6, e) welding current and arc voltage during starting phase, virtual measuring unit KWRI in LabView application

Kolejne eksperymenty polegały na wykorzystaniu funkcji monitorująco - kontrolnych wbudowanych w źródło TPS 2700CMT. Procedura „ARC Break Watchdog” pozwala na automatyczne rozpoznawanie przepalenia i reakcję obronną - zatrzymanie procesu. W tym celu powtórzono wcześniej omówioną próbę nr 15 z dodaniem funkcji ARC i zmiennymi nastawami sterującymi (tabl. II). Niestety, w żadnym z przypadku nie uzyskano zadowalającego rezultatu. W celu sprawdzenia przyczyn małej skuteczności, przeprowadzono dodatkowy test napawania na krawędzi blachy - z kontynuacją ruchu robota i procesu pomimo zejścia z próbki (rys. 8). Każdorazowo mierzono długość wysuniętego odcinka drutu $(\mathrm{H})$ i odległość od krawędzi blachy (S), jaką przebywał robot do zatrzymania (robot połączony ze źródłem interfejsem ROB 3000 zatrzymywał ruch z chwilą awaryjnego wyłączenia łuku). Widać, że nawet minimalna nastawa funkcji kontrolnej powodowała wyraźne "opóźnienie" reakcji układu (tabl. II, rys. 8/c). Powodem może być, oprócz naturalnych opóźnień komunikacyjnych oraz reakcji napędzanych mechanizmów robota i podajnika drutu, także zaobserwowane zjawisko niewielkiego ugięcia łuku, podtrzymujące jego trwanie jeszcze chwilę poza krawędzią blachy. Pozytywny rezultat próby uzyskano dopiero podczas napawania na obwodzie cienkościennego, stalowego płaszcza (grubość blachy 0,8 mm, średnica ok. $200 \mathrm{~mm}$ ). Uznano, że warunkiem skutecznego zadziałania funkcji kontroInej ARC jest dostatecznie duży otwór w skutek przepalenia oraz brak możliwości podtrzymania jarzenia łuku np. podkładką od strony grani, elementami oprzyrządowania czy spawanej konstrukcji.

Tablica II. Nastawy sterujące funkcji „ARC Break Watchdog” (Fronius) oraz długość wysuniętego drutu $(\mathrm{H})$ i odległość od krawędzi blachy (S)

Table II. Control settings of the function "ARC Break Watchdog" (Fronius) and welding electrode stick out $(\mathrm{H})$ and its distance from plate edge (S)

\begin{tabular}{|c|c|c|}
\hline $\begin{array}{c}\text { nastawy sterujące } \\
\text { ARC Break Watchdog [s] }\end{array}$ & $\mathbf{H}[\mathbf{m m}]$ & $\mathbf{S}[\mathbf{m m}]$ \\
\hline 0,20 & 18,4 & 6,0 \\
\hline 0,10 & 12,5 & 5,6 \\
\hline 0,01 & 8,6 & 5,3 \\
\hline
\end{tabular}

Drugą, przetestowaną wbudowana funkcją monitorującą źródła TPS 2700CMT była procedura ITO (ang. Ignition Time-Out), służąca do wykrywania niezajarzenia łuku. W przypadku braku łuku urządzenie, po odwinięciu nastawionej długości drutu, zatrzymuje proces i wyświetla odpowiedni komunikat. W praktyce może to uchronić $\mathrm{np}$. przed zapętleniem drutu w podajniku, a nawet wewnątrz pancerza prowadzącego do uchwytu elektrodowego. W tym przypadku wykazano wysoką skuteczność działania funkcji kontrolnej.

W trakcie badań ujawniono niekiedy bardzo duże rozbieżności w wartościach średnich prądu i napięcia wskazywanych przez niektóre systemy i mierniki. W następstwie stwierdzonych różnic przeprowadzono dalsze badania porównawcze dla wytypowanych mierników. Pomiary wykonywano podczas prostoliniowego, niezakłóconego napawania różnymi odmianami metody MAG. W roli przyrządu odniesienia wykorzystano oscyloskop Siglent SDS1072CML 70MHz i dostępne w nim funkcje obliczeniowe, w tym wyznaczania wartości średniej i średniej skutecznej AC+DC dla zadanego przebiegu (rys. 9). W tablicach III do V zestawiono wybrane wyniki pomiarów.

Jak można zauważyć, zarówno wartości prądu spawania jak i napięcia łuku otrzymane podczas pomiaru poszczególnymi miernikami różniły się. Przyczyną są zarówno różnice klas dokładności poszczególnych przyrządów, zastosowane w nich metody uśredniania wyników oraz moment dokonania pomiaru (starano się 

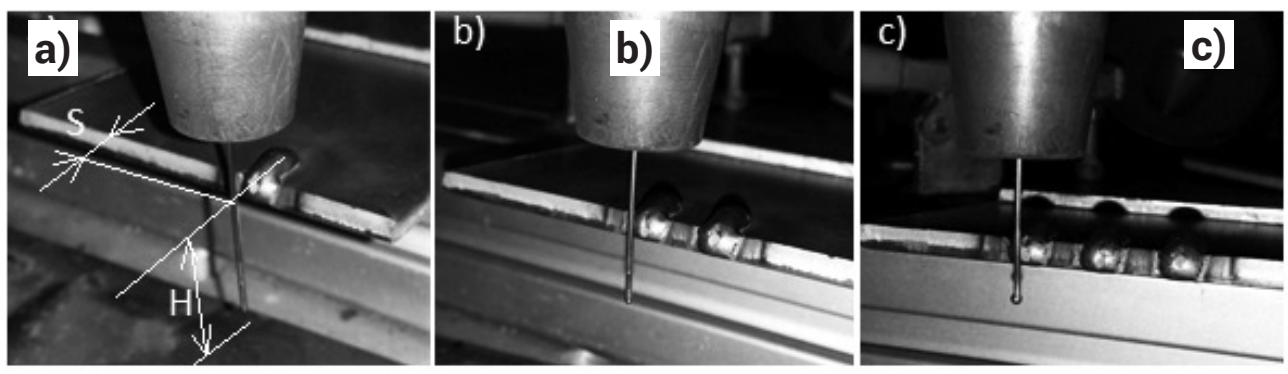

Rys. 8. Długość wysuniętego drutu (H) i odległość od krawędzi blachy (S) podczas testów dla poszczególnych nastaw funkcji "ARC Break Watchdog": a) 0,20s, b) 0,10s, c) 0,01s

Fig. 8. Welding electrode wire stickout $(\mathrm{H})$ and its distance from plate edge (S) during tests of such functions as "ARC Break Watchdog": a) $0.20 \mathrm{sec}$, b) $0.10 \mathrm{sec}, \mathrm{c}) 0.01 \mathrm{sec}$

dokonywać odczytów przez kilka osób równocześnie). Największe różnice dotyczyły jednak przyjętej metody uśredniania wyników. Za każdym razem wyniki pomiarów wartości średniej (podstawowa funkcja typowych mierników technicznych) są znacznie niższe niż wartości średnich skutecznych (nastawy TRUE RMS AC+DC). W odniesieniu do pomiarów napięcia największe różnice odnotowano przy metodzie MAG CMT (różnica ok. 6V), prąd najbardziej różnił się podczas napawania metodą MAG Puls (różnica ok. 30A). Najbardziej wyrównane wskazania otrzymano dla napawania podstawową, niesterowaną odmianą MAG Synergic. Jak widać, charakter nieliniowego odkształcenia mierzonych sygnałów miał $w$ tym wypadku decydujący wpływ na zmierzone wartości. Metoda MAG synergic, niezależnie od sposobu przechodzenia kropli w łuku (zwarciowego czy natryskowego), charakteryzująca się mniejszym stopniem i dynamiką odkształcenia przebiegów prądu i napięcia w stosunku do odmiany CMT czy prądu pulsującego MAG Puls, dała najmniej zróżnicowane wyniki pomiarów.

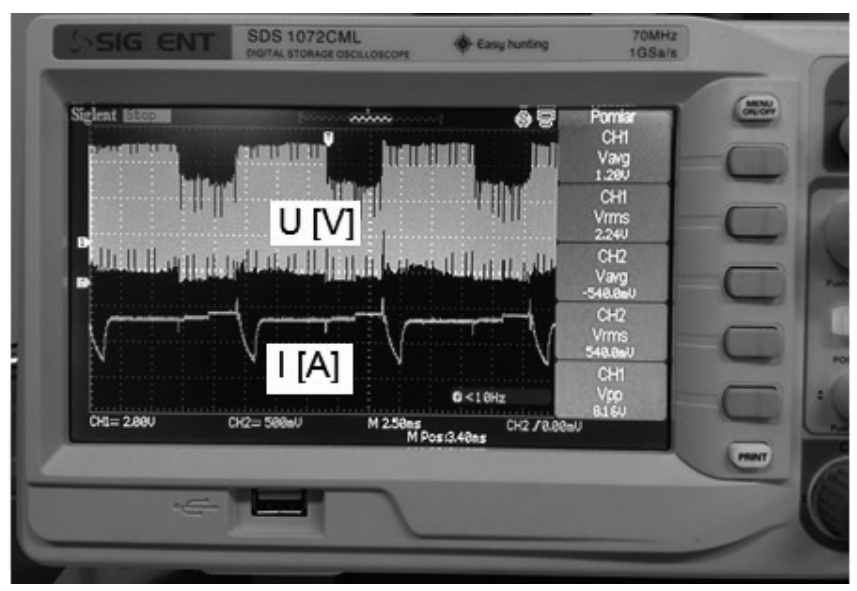

Rys. 9. Widok zarejestrowanego przebiegu zmian prądu i napięcia podczas napawania metodą MAG CMT z aktywną funkcją obliczeniową wartości średnich (prawa strona ekranu)

Fig. 9. Screen view of current and voltage waveforms recorded during MAG CMT surfacing with average values showed on left hand side

Tablica III. Zmierzone wartości prądu spawania i napięcia łuku podczas napawania metodą MAG CMT (nastawiono 96A, 12,7V, średnica drutu $0,8 \mathrm{~mm}$, prędkość spawania $7,5 \mathrm{~mm} / \mathrm{s}$ )

Table III. Measured values of welding current and arc voltage during MAG CMT surface welding (settings: current 96A, voltage 12.7V, wire dia. $0.8 \mathrm{~mm}$, welding speed $7.5 \mathrm{~mm} / \mathrm{sec}$ )

\begin{tabular}{|l|c|c|c|c|}
\hline \multirow{2}{*}{ MAG CMT } & \multicolumn{2}{|c|}{ Prąd spawania [A] } & \multicolumn{2}{c|}{ Napięcie łuku [V] } \\
\cline { 2 - 5 } & Wartość średnia & $\begin{array}{c}\text { Wartość skuteczna } \\
\text { AC+DC }\end{array}$ & Wartość średnia & $\begin{array}{c}\text { Wartość skuteczna } \\
\text { AC+DC }\end{array}$ \\
\hline $\begin{array}{l}\text { Wskaźniki źródła TPS } \\
\text { 2700CMT }\end{array}$ & 95,0 & - & 13,6 & - \\
\hline Cęgi TES 3060 & 97,7 & - & - & - \\
\hline Cęgi APPA138 & 95,8 & 113,0 & - & 14,1 \\
\hline Yokogawa TY720 & - & - & 14,4 & 20,3 \\
\hline Oscyloskop & 94,0 & 108,0 & & 20,1 \\
\hline
\end{tabular}

Tablica IV. Zmierzone wartości prądu spawania i napięcia łuku podczas napawania metodą MAG PULS (nastawiono 60A, 20,2V, średnica drutu $0,8 \mathrm{~mm}$, prędkość spawania $7,5 \mathrm{~mm} / \mathrm{s}$ )

Table IV. Measured values of welding current and arc voltage during MAG PULS surface welding (settings: current $60 \mathrm{~A}$, voltage 20.2V, wire dia. $0.8 \mathrm{~mm}$, welding speed $7.5 \mathrm{~mm} / \mathrm{sec}$ )

\begin{tabular}{|l|c|c|c|c|}
\hline \multirow{2}{*}{ MAG PULS } & \multicolumn{2}{|c|}{ Prąd spawania [A] } & \multicolumn{2}{c|}{ Napięcie łuku [V] } \\
\cline { 2 - 5 } & Wartość średnia & $\begin{array}{c}\text { Wartość skuteczna } \\
\text { AC+DC }\end{array}$ & Wartość średnia & $\begin{array}{c}\text { Wartość skuteczna } \\
\text { AC+DC }\end{array}$ \\
\hline $\begin{array}{l}\text { Wskaźniki źródła TPS } \\
\text { 2700CMT }\end{array}$ & 61,0 & - & 22,2 & - \\
\hline Cęgi TES 3060 & 62,3 & - & - & - \\
\hline Cęgi APPA138 & 60,5 & 94,5 & - & 21,2 \\
\hline Yokogawa TY720 & - & - & 20,8 & 24,6 \\
\hline Oscyloskop & 60,0 & 90,0 & & 24,0 \\
\hline
\end{tabular}


Tablica V. Zmierzone wartości prądu spawania i napięcia łuku podczas napawania metodą MAG Synergic (nastawiono 80A, 16,4V, średnica drutu $0,8 \mathrm{~mm}$, prędkość spawania $7,5 \mathrm{~mm} / \mathrm{s}$ )

Table V. Measured values of welding current and arc voltage during MAG Synergic surface welding (settings: current $80 \mathrm{~A}$, voltage $16.4 \mathrm{~V}$, wire dia. $0.8 \mathrm{~mm}$, welding speed $7.5 \mathrm{~mm} / \mathrm{sec}$ )

\begin{tabular}{|l|c|c|c|c|}
\hline \multirow{2}{*}{ MAG Synergic } & \multicolumn{2}{|c|}{ Prąd spawania [A] } & \multicolumn{2}{c|}{ Napięcie łuku [V] } \\
\cline { 2 - 5 } & Wartość średnia & $\begin{array}{c}\text { Wartość skuteczna } \\
\text { AC+DC }\end{array}$ & Wartość średnia & $\begin{array}{c}\text { Wartość skuteczna } \\
\text { AC+DC }\end{array}$ \\
\hline $\begin{array}{l}\text { Wskaźniki źródła TPS } \\
\text { 2700CMT }\end{array}$ & 82,0 & - & 17,2 & - \\
\hline Cęgi TES 3060 & 85,0 & - & - & - \\
\hline Cęgi APPA138 & 82,4 & 90,6 & - & - \\
\hline Yokogawa TY720 & - & - & 17,3 & 20,5 \\
\hline Oscyloskop & 84,1 & 88,0 & 17,6 & 20,8 \\
\hline
\end{tabular}

\section{Podsumowanie}

Badania potwierdziły przydatność spawalniczych systemów monitorujących do bieżącej analizy i kontroli procesu. Przewaga choćby najprostszej rejestracji (jak w robocie IRp-6) nad ręcznym, chwilowym pomiarem jest oczywista. Możliwe stało się ujawnienie poważnego zakłócenia (skutkującego przepaleniem).

Oscyloskopy i wirtualne narzędzia pomiarowe dają wgląd w szczegółowy obraz zmian prądu i napięcia, maja jednak głównie znaczenie badawcze. W tym wypadku oczekiwana jest komercyjna, skuteczna metoda rozpoznawania niezgodności spawalniczych m.in. na podstawie zaburzeń prądu spawania i napięcia łuku.

Wbudowane systemy monitorująco - nadzorujące, jak testowana funkcja ARC, są cennym uzupełnieniem systemów monitorujących, jednak ich praktyczne wykorzystanie wymaga szczegółowej analizy oraz doświadczenia operatora.

Podczas pomiarów parametrów elektrycznych obwodu spawalniczego pojawia się szereg problemów, takich jak okresowo zmienne odkształcenia mierzonych wartości, odkształcenia niesinusoidalne, sygnały wykraczające poza pasmo pomiarowe typowych mierników, a także różne zakłócenia i tętnienia, których nie można ignorować. Praktyka pomiarów elektrycznych wskazuje, że dla silnie odkształconych przebiegów niesinusoidalnych wskazane są pomiary wartości skutecznej. W trakcie badań stwierdzono nawet kilkudziesięcioprocentowe różnice pomiędzy wartościami prądu oraz napięcia mierzonym uśrednianymi arytmetycznie i do wartości skutecznej. Wartości skuteczne zawsze były znacznie wyższe, a więc i wielkości energii liniowej obliczone według takiej metody znacznie by się różniły od wyznaczanych podczas tradycyjnego pomiaru. Wykazano przy tym, że zarówno wskaźniki na płycie czołowej źródła TPS 2700CMT, dedykowany rejestrator RCU 5000i, jak i podstawowe mierniki prądu i napięcia nie mierzą wartości skutecznej. Tego typu pomiar jest domeną przyrządów zaawansowanych, oscyloskopów czy też badawczych systemów wirtualnych. Pozostaje zatem nadal korzystać z podstawowej metody uśredniania, mając jednocześnie świadomość, że różnica w wynikach pomiarów pogłębia się w miarę pojawiania nowych, sterowanych odmian procesu MIG/MAG.

\section{Literatura}

[1] Cegielski P., Kolasa A., Sarnowski T., Silbert B. „Koncepcja systemów monitorowania spawalniczych stanowisk zrobotyzowanych" Przegląd Spawalnictwa, 8-10/2002, str. 181-184.

[2] Cegielski P., Kolasa A., Sarnowski T., Silbert B., Michalis A. „System interfejsów sterujących i monitorowania zrobotyzowanego spawania łukowego" Przegląd Spawalnictwa, 5-7/2004, str. 85-88.

[3] Cegielski P. „Pomiary w procesach spawalniczych cz.1” Przegląd Spawalnictwa $7 / 2016$, str. $52-53$

[4] Cegielski P. „Pomiary w procesach spawalniczych cz.2” Przegląd Spawalnictwa 11/2016, str. 53-54.

[5] Cegielski P., Kolasa A., Skrzyniecki K., Kołodziejczak P. "Komputerowy system do badań właściwości statycznych i dynamicznych źródeł energii elektrycznej do spawania łukowego" Przegląd spawalnictwa 1/2012, str. 3-9.

[6] Cegielski P., Skrzyniecki K., Kolasa A., Kołodziejczak P. „Badania stabilności układu łuk - urządzenie zasilające w warunkach symulowanych zakłóceń procesu spawania metodą MAG" Przegląd Spawalnictwa 4/2013, str. 18-27.
[7] Doliński J. „Multimetry TRMS” Elektronika Praktyczna 9/2009, str.77-83.

[8] Doliński J. „Świadomość pomiarów” Elektronika Praktyczna 10/2014, str. 83-85.

[9] Jemielniak K. "Techniki wytwarzania 2. Część 7. Automatyczna diagnostyka stanu narzędzia i procesu skrawania", materiały pomocnicze do ćwiczeń, Zakład Automatyzacji, Obrabiarek i Obróbki Skrawaniem PW.

[10] Kolasa A., Cegielski P., Skrzyniecki K. Sprawozdanie merytoryczne z realizacji projektu badawczego własnego N N503 206339/2063/B/ T02/2010/39 „Badanie zależności pomiędzy zjawiskami zachodzącymi w łuku spawalniczym w różnych odmianach metody MAG, a parametrami elektrycznymi układu łuk - urządzenie spawalnicze", Politechnika Warszawska 12/2013.

[11] Kurs aktualizacji wiedzy dla Europejskiego Inżyniera spawalnika. Instytut Spawalnictwa, Gliwice 1998.

[12] Luksa K., Fitrzyk J., Szpakowski E. „Analiza parametrów metodą wykrywania zakłóceń procesu spawani" Przegląd Spawalnictwa 11/2012, str. 29-34.

[13] Strona internetowa: http://www.iso9001.org.pl/iso_wymagania_dla_ procesow_spawania (stan na 12.2016). 